 \\ International Journal of Social Sciences and Management
}

A Rapid Publishing Journal

ISSN 2091-2986

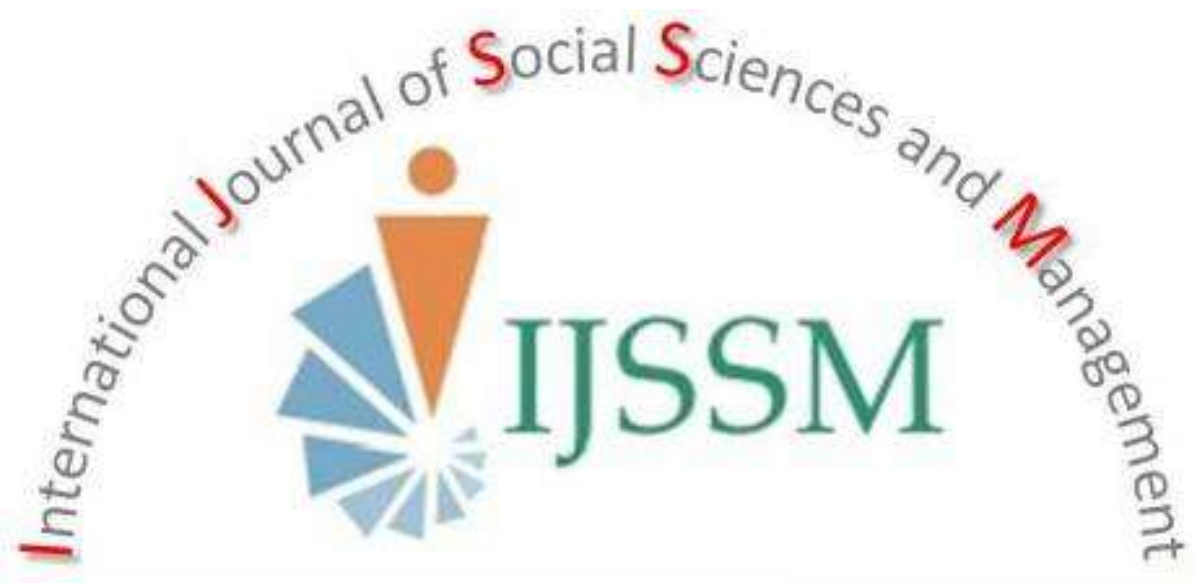

Available online at:

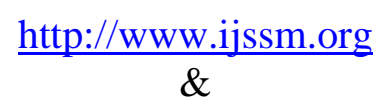

http://www.nepjol.info/index.php/IJSSM/index

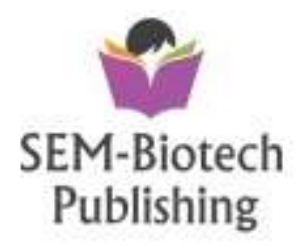




\title{
CUSTOMERS PREFERENCE ATTRIBUTES IN THE USAGE OF CORE BANKING SERVICES: AN EMPIRICAL INVESTIGATION
}

\author{
Repalle Giddaiah* and Padmasree Karamala \\ Department of Commerce, School of Business studies, Central University of Karnataka, Gulbarga, Karnataka, India \\ ${ }^{\star}$ Corresponding author email: repallegiddaiah@gmail.com
}

\begin{abstract}
Core banking services are increasingly becoming popular because of convenience and flexibility. The study was undertaken all the banking customers of Nandyal town. The sample size of the study was 250 . The present study is based on the primary as well secondary data. The primary data is collected from the bank customers who are residing in Nandyal town. Data is analyzed and presented in tables. Statistical tools like percentages and weighted average method were used with the help of SPSS packages. The paper examines to know the customer preference attributes in the usage of core banking services and factors affected them in using core banking services. The finding of the study, majority of the customers are preference is given by attributes convenience, availability of places, safety and security and familiarity of services followed by attributes cost of transactions, reliability, and availability of time and accessibility of services. The study is useful to the corporate world to tap this area and improve the e-service standards of the banking sector.
\end{abstract}

Keywords: Core banking services; customer preference; attributes.

\section{Introduction}

In the banking sector, Information Technology has shrunken the world, as a result of which, time and distance have become non-entities. It has enveloped every aspect of life. In this changing scenario, the concept of banking has drastically changed, where technology is the most dominating factor which has helped the banks to provide innovative banking services/ products.

Now a days Core banking solutions (CBS) helps automated front-end and back-end processes of banks to achieve centralized and smooth processing. These applications offer a single view of the customer and facilitate automation across delivery channels. The concept of CBS has helped banks to become one-stop shops for all the financial needs of retail and corporate customers by offering multiple services under one roof. Core banking can be defined as provision of banking products and services through electronic platforms such as ATM, Internet banking and mobile or irrespective of braches (Nitsure, 2003). Hence customers can access their accounts from any branch of their bank, irrespective of which branch the account was opened at. Currently, the number of bank branches in India with CBS implementation increasing by year-over-year.

Recently, The Union Government of India on 15 October 2013 decided to bring all the post offices across India under the core banking solution system to cover more people of urban and rural areas connected with AADHAAR seeded accounts, MGNREGA through direct benefits transfer and AADHAR card linked with bank accounts. It is a modern platform established for Indian Banking industry with an objective of increasing the productivity and efficiency of banks, reducing manual errors which are committed while recording a banking transaction and increasing transparency in all banking transactions.

The Table 1 shows some of the related study reviewed on customers preference attributes in the usage of core banking services 
Table 1: Summary of Studies Dealing with Customers Preference Attributes in the Usage of Core Banking Services

\begin{tabular}{|c|c|c|c|}
\hline Investigator & Attributes & Statistical tools & Findings of the Study \\
\hline $\begin{array}{l}\text { Safeena et al. } \\
(2010)\end{array}$ & $\begin{array}{l}\text { Perceived } \\
\text { use,Consumer } \\
\text { Awareness }\end{array}$ & $\begin{array}{l}\text { Likert Scale and } \\
\text { Cronbach's } \\
\text { coefficient alpha }\end{array}$ & $\begin{array}{l}\text { They found that perceived usefulness, perceived ease of } \\
\text { use and consumer awareness are the important } \\
\text { determinants of online banking adoption. }\end{array}$ \\
\hline Khan (2010) & $\begin{array}{l}\text { Convenience, } \\
\text { Reliability } \\
\text { andEase of use }\end{array}$ & $\begin{array}{l}\text { Mean T-Test, ANOVAs } \\
\text { and Correlation. }\end{array}$ & $\begin{array}{l}\text { His study concluded reliability, ease of use, privacy, } \\
\text { convenience, efficiency and responsiveness as the key } \\
\text { dimensions of service quality. }\end{array}$ \\
\hline $\begin{array}{l}\text { Laukkanen, } \\
2006\end{array}$ & $\begin{array}{l}\text { Safety and } \\
\text { Security }\end{array}$ & $\begin{array}{l}\text { Laddering Technique and } \\
\text { Means-End Approach }\end{array}$ & $\begin{array}{l}\text { He explored privacy and security followed by safety } \\
\text { related factors as major subjective factors in the } \\
\text { acceptance of e-banking services. }\end{array}$ \\
\hline IAMAI, 2006 & $\begin{array}{l}\text { Convenience } \\
\text { and Service } \\
\text { preferability }\end{array}$ & $\begin{array}{l}\text { Percentage and Factor } \\
\text { Analysis }\end{array}$ & $\begin{array}{l}\text { It was noticed that respondents were most preferred } \\
\text { ATM followed by internet banking and mobile banking } \\
\text { among the e-channels. The study found that convenience } \\
\text { as most important factor whiles the use of core banking } \\
\text { services. }\end{array}$ \\
\hline Katono, 2011 & $\begin{array}{l}\text { Reliability, } \\
\text { Location and } \\
\text { Availibity }\end{array}$ & $\begin{array}{l}\text { Both Exploratory and } \\
\text { Confirmatory Factor } \\
\text { analysis and Linear } \\
\text { regression }\end{array}$ & $\begin{array}{l}\text { He Study discovered that tangibles, card issues, } \\
\text { reliability and location are the most important factors } \\
\text { student service quality Evaluation dimensions of ATMs. }\end{array}$ \\
\hline $\begin{array}{l}\text { Mohan and } \\
\text { Goyal, } 2012\end{array}$ & $\begin{array}{l}\text { Security and } \\
\text { privacy }\end{array}$ & Multiple Regression & $\begin{array}{l}\text { Their survey concluded main problem lies that still } \\
\text { customer have a fear of hacking of accounts and thus do } \\
\text { not go on for internet banking. }\end{array}$ \\
\hline $\begin{array}{l}\text { Williamson, } \\
2006 ; \\
\text { Liu and Arnett, } \\
2007\end{array}$ & $\begin{array}{l}\text { Time factor and } \\
\text { Saving } \\
\text { Transaction cost, }\end{array}$ & $\begin{array}{l}\text { Five-point Likert scale } \\
\text { and percentages }\end{array}$ & $\begin{array}{l}\text { The study pointed that saving time is an important factor } \\
\text { which influences the customers prefers to use i-banking } \\
\text { it would stand in the way of consumer adoption of } \\
\text { Internet banking is the transaction cost factor. }\end{array}$ \\
\hline $\begin{array}{l}\text { Srivastava, } \\
2009\end{array}$ & $\begin{array}{l}\text { Faster Transfer } \\
\text { And Quick } \\
\text { access }\end{array}$ & $\begin{array}{l}\text { Factor Analysis,Kaiser- } \\
\text { Mayer-Olkin (KMO) } \\
\text { and Barlett's Test }\end{array}$ & $\begin{array}{l}\text { The study revealed quick access is vital factor which } \\
\text { influence the customers prefers before using of } \\
\text { electronic banking services any place at any time with a } \\
\text { mouse clicks distance. }\end{array}$ \\
\hline
\end{tabular}

In Light of the previous findings shown in Table-1, majority of the customers prefer to availing e-banking services, but at the same time, still they have express different thoughts and perception while using core banking services due to which they are unable to take full advantage of e-services. However, most of the studies are carried out in home and foreign countries. Such studies are required, particularly in the region wise to improve the banking services through electronically. Hence the present study was undertaken various customer preference attributes like Convenience, Availability of Time, Accessibility of Services, Availability of Places, Cost of Transactions, Safety and Security, Familiarity of Services, Reliability and Quick accessibility were identified to be crucial attributes of before using the Core banking services. The present study to know the customer preference attributes while using the core banking services and also to identify the factors influence by the customers before using the banking services in Nandyal town.

\section{Objectives of the Study}

The objectives of this study are as follows:

1. To examine the customers' preference attributes in the usage of Core Banking Solutions; and

2. To identify the customer preference attributes and improving core banking services.

\section{Research Methodology}

The study is descriptive in nature. The present study is based on primary as well as secondary data. Primary data is collected from the bank customers who are residing in Nandyal town. All the banking customers were having electronic banking services in Nandyal town from the universe for the present study. A sample of 300 customers was chosen for the study. Among them only 250 were responded to the questionnaire distributed. The data was collected from Dec 2013 to Feb 2014. The relevant data has been grouped and presented in tables. The responses of 250 respondents have been subjected to statistical tools like percentages, rank analysis followed by weighted average method were applied. The data of the study has been analyzed through SPSS (Statistical Package for Social Sciences) version 16 for windows. To know the customers preference attributes while using core banking services for Likert scale method was chosen and respondents were assign ranks from 1 (most preferred) to 8 (less preferred) and secondary data is obtained from the journals to the relevant aspects.

\section{Data Analysis}


Table 1: Gender wise classification of the respondents in Nandyal Town

\begin{tabular}{|l|l|l|}
\hline Gender & Respondents & Percentage \\
\hline Male & 159 & $63.60 \%$ \\
\hline Female & 91 & $36.40 \%$ \\
\hline Total & 250 & $100.00 \%$ \\
\hline
\end{tabular}

The result shown in Table-1 states that 159 (63.60\%) respondents were males and remaining respondents were females i.e., majority of the respondents were from male category.

Table 2: Age-wise classification of the respondents in Nandyal Town

\begin{tabular}{|l|l|l|}
\hline Age & Respondents & Percentage \\
\hline $18-25$ & 76 & $30.40 \%$ \\
\hline $26-30$ & 77 & $30.80 \%$ \\
\hline $31-35$ & 51 & $20.40 \%$ \\
\hline $36-40$ & 26 & $10.40 \%$ \\
\hline Above 40 & 20 & $8.00 \%$ \\
\hline Total & 250 & $100.00 \%$ \\
\hline
\end{tabular}

It is evident with Table-2 that out of 250 respondents 76 $(30.40 \%)$ respondents were under the age group of $18-25$ years and $77(30.80 \%)$ of the respondents were between 26 30 years, $51(20.40 \%)$ respondents were between 31-35 years, $26(10.40 \%)$ respondents were between $36-40$ years and $20(8.00 \%)$ respondents were under the age of above 45 years. It is evident from the table that the most of the respondents were between 18 to 30 years.

Table 3: Education wise classification of respondents in Nandyal town

\begin{tabular}{|l|l|l|l|}
\hline Education & & Respondents & Percentage \\
\hline Below SSC & 26 & $10.40 \%$ \\
\hline SSC & 24 & $9.60 \%$ \\
\hline Inter & 51 & $20.40 \%$ \\
\hline Graduate & 99 & $39.60 \%$ \\
\hline Postgraduate & 50 & $20.00 \%$ \\
\hline Total & 250 & $100.00 \%$ \\
\hline
\end{tabular}

Source: Primary data

Table 4: Occupation wise details of respondents in Nandyal Town

\begin{tabular}{|l|l|l|}
\hline Occupation & Respondents & Percentage \\
\hline Student & 65 & $26.00 \%$ \\
\hline Employees & 102 & $40.80 \%$ \\
\hline Business & 35 & $14.00 \%$ \\
\hline Others & 48 & $19.20 \%$ \\
\hline Total & 250 & $100.00 \%$ \\
\hline
\end{tabular}

Source: Primary data

Data shown in Table-3 reveals that 26 (10.40\%) respondents had education below SSC, 24 (9.60\%) respondents had SSC education, $51(20.40 \%)$ respondents were intermediate, $99(39.60 \%)$ respondents were graduates and $50(20.00 \%)$ respondents were post graduates. It indicates that most of the respondents were well educated i.e., they were either graduates or post graduates.

Table-4 portrays that $65(26.00 \%)$ respondents were students, $102(40.80 \%)$ respondents were employed, 35 $(14.00 \%)$ respondents were in business and $48(19.20 \%)$ respondents were belong to other occupations. It shows that the majority of the respondents were employees followed by students.

Table 5: Frequency in Use of CBS in a month by the Respondents

\begin{tabular}{|l|l|l|}
\hline Usage & Respondents & Percentage \\
\hline Once & 16 & $6.04 \%$ \\
\hline Twice & 46 & $18.40 \%$ \\
\hline Thrice & 83 & $33.20 \%$ \\
\hline $\begin{array}{l}\text { More than three } \\
\text { times }\end{array}$ & 105 & $42.00 \%$ \\
\hline Total & 250 & $100.00 \%$ \\
\hline
\end{tabular}

Source: Primary data

Table-5 explains that $16(6.04 \%)$ respondents use CBS services once in month, $46(18.40 \%)$ respondents use twice in a month, $83(33.20 \%)$ respondents use thrice in a month and $105(42.00 \%)$ respondents using services more than three times in a month. It indicates that the majority of respondents are using any one of the CBS services several times in a month.

Table 6: Service wise classification of the respondents in Nandyal Town

\begin{tabular}{|l|l|l|}
\hline CBS Service & Respondents & Percentage \\
\hline $\begin{array}{l}\text { Online/ Internet } \\
\text { banking }\end{array}$ & 44 & $17.60 \%$ \\
\hline ATM & 206 & $82.40 \%$ \\
\hline $\begin{array}{l}\text { Telephone } \\
\text { banking }\end{array}$ & - & - \\
\hline Mobile banking & - & - \\
\hline Total & 250 & $100.00 \%$ \\
\hline
\end{tabular}

Table-6 states that $206(82.40 \%)$ respondents were prefer ATM service and remaining respondents were prefer Internet/Online banking service and nobody were preferred mobile and tele phone banking. Its reveals that majority of the respondents were preferred ATM service.

Table 7 gives the total scores assigned for each of the preference attributes while using core banking services of the respondents. The factors preferred by customers while using core banking services were listed and based on the fortitude, the respondents assigned ranks 1 to 8 . The respondents were asked to assign ranks from 1 to 8 based on their preferences for various factors. The ranks were converted into weights. Weights were assigned in the reverse order; for rank 1weights 10; for rank 2 weights 9 and so on. 
Table7: Rank wise Classification of Total Respondents

\begin{tabular}{|c|c|c|c|c|c|c|c|c|c|}
\hline Factors & R1 & $\mathbf{R 2}$ & $\mathbf{R 3}$ & $\mathbf{R 4}$ & $\mathbf{R 5}$ & R6 & R7 & R8 & $\begin{array}{l}\text { Total } \\
\text { Respondents }\end{array}$ \\
\hline Convenience & 96 & 89 & 33 & 02 & 07 & 13 & - & 10 & 250 \\
\hline Safety/Security & 85 & 25 & 12 & 18 & 07 & 15 & 31 & 57 & 250 \\
\hline Availability of Places & 40 & 46 & 41 & 58 & 43 & 04 & 04 & 14 & 250 \\
\hline Accessibility of services & 15 & 15 & 16 & 17 & 02 & 89 & 14 & 82 & 250 \\
\hline Availability of Time & 06 & 29 & 47 & 26 & 02 & 32 & 73 & 35 & 250 \\
\hline Familiarity of services & 04 & 31 & 59 & 22 & 21 & 01 & 94 & 18 & 250 \\
\hline Reliability & 04 & 13 & 27 & 51 & 51 & 70 & 01 & 33 & 250 \\
\hline Cost of Transactions & - & 02 & 15 & 56 & 117 & 26 & 33 & 01 & 250 \\
\hline Total Respondents & 250 & 250 & 250 & 250 & 250 & 250 & 250 & 250 & - \\
\hline
\end{tabular}

Source: Compiled data.

Table-8 Consolidation of Customer preference attributes (CWA)

\begin{tabular}{|c|c|c|c|c|c|c|c|c|c|c|c|c|}
\hline \multicolumn{2}{|c|}{ Rank (X) } & 1 & 2 & 3 & 4 & 5 & 6 & 7 & 8 & \multirow[t]{2}{*}{ Total } & \multirow[t]{2}{*}{$\mathbf{C W}$} & \multirow[t]{2}{*}{ Rank } \\
\hline \multicolumn{2}{|c|}{ Weights (W) } & 10 & 9 & 8 & 7 & 6 & 5 & 4 & 3 & & & \\
\hline \multirow[t]{2}{*}{ Convenience } & $\mathrm{X} 1$ & 96 & 89 & 33 & 02 & 07 & 13 & 0 & 10 & 250 & \multirow[t]{2}{*}{8.70} & \multirow[t]{2}{*}{1} \\
\hline & WX1 & 960 & 801 & 264 & 14 & 42 & 65 & 0 & 30 & 2176 & & \\
\hline \multirow{2}{*}{$\begin{array}{l}\text { Safety/ } \\
\text { Security }\end{array}$} & $\mathrm{X} 2$ & 85 & 25 & 12 & 18 & 07 & 15 & 31 & 57 & 250 & \multirow[t]{2}{*}{6.83} & \multirow[t]{2}{*}{3} \\
\hline & WX2 & 850 & 225 & 96 & 126 & 42 & 75 & 124 & 171 & 1709 & & \\
\hline \multirow{2}{*}{$\begin{array}{c}\text { Availability } \\
\text { of Places }\end{array}$} & $\mathrm{X} 3$ & 40 & 46 & 41 & 58 & 43 & 04 & 04 & 14 & 250 & \multirow[t]{2}{*}{7.53} & \multirow[t]{2}{*}{2} \\
\hline & WX3 & 400 & 414 & 328 & 406 & 258 & 20 & 16 & 42 & 1884 & & \\
\hline \multirow{2}{*}{$\begin{array}{c}\text { Accessibility of } \\
\text { Services }\end{array}$} & $\mathrm{X} 4$ & 15 & 15 & 16 & 17 & 02 & 89 & 14 & 82 & 250 & \multirow[t]{2}{*}{5.16} & \multirow[t]{2}{*}{8} \\
\hline & WX4 & 150 & 135 & 128 & 119 & 12 & 445 & 56 & 246 & 1291 & & \\
\hline \multirow{2}{*}{$\begin{array}{c}\text { Availability } \\
\text { of Time }\end{array}$} & $\mathrm{X} 5$ & 06 & 29 & 47 & 26 & 02 & 32 & 73 & 35 & 250 & \multirow[t]{2}{*}{5.79} & \multirow[t]{2}{*}{7} \\
\hline & WX5 & 60 & 261 & 376 & 182 & 12 & 160 & 292 & 105 & 1448 & & \\
\hline \multirow{2}{*}{$\begin{array}{l}\text { Familiarity } \\
\text { of Services }\end{array}$} & X6 & 04 & 31 & 59 & 22 & 21 & 01 & 94 & 18 & 250 & \multirow[t]{2}{*}{6.13} & \multirow[t]{2}{*}{4} \\
\hline & WX6 & 40 & 279 & 472 & 154 & 126 & 05 & 376 & 54 & 1506 & & \\
\hline \multirow[b]{2}{*}{ Reliability } & $\mathrm{X} 7$ & 04 & 13 & 27 & 51 & 51 & 70 & 01 & 33 & 250 & \multirow[t]{2}{*}{5.81} & \multirow[t]{2}{*}{6} \\
\hline & WX7 & 40 & 117 & 216 & 357 & 306 & 350 & 04 & 99 & 1489 & & \\
\hline \multirow{2}{*}{$\begin{array}{c}\text { Cost of } \\
\text { Transactions }\end{array}$} & X8 & 0 & 02 & 15 & 56 & 117 & 26 & 33 & 01 & 250 & \multirow[t]{2}{*}{5.93} & \multirow[t]{2}{*}{5} \\
\hline & WX8 & 0 & 18 & 120 & 392 & 702 & 130 & 132 & 03 & 1497 & & \\
\hline
\end{tabular}

Source: Complied data. CW-Cumulative Weights

Table 8 list of the factors with the rank and weights assigned. The customer's highest preference was for Convenience with the maximum weights of 2175 (8.70) followed by availability of places of 1884 (7.53), safety and security of 1709 (6.83) and familiarity of services of 1506 (6.13). Accessibility of services got the lowest weights 1291 (5.16). On probe it was found that most of the respondents were preferred on need basis even though they bother about convenience and safety/security issues not the cost, time and services.

\section{Findings and Conclusions}

From the study found that majority of the respondents availing core banking services were between 18 to 25 years age group, having education of graduation and postgraduation levels. Most of the respondents were preferred for ATM and internet/online banking services more than three times in a month but nobody were preferred for mobile and telebanking services. The findings of the study shows that the majority of the respondents were preferred firstly four and foremost attributes convenience, availability of places, safety and security and familiarity of services. The second four attributes gives cost of transactions, reliability, availability of time and accessibility of services (Table 8).The customer's highest preference is given for first major attributes convenience, availability of places, safety and security and familiarity of services. The second four attributes gives cost of transactions, reliability, availability of time and accessibility of services.

The majority of the respondents were using core banking services not only based on their convenience and availability of places, even though they were afraid of regarding safety and security. hence, they were using among core banking service whichever is familiar and aware. Most of respondents were problem faced by the accessibility of services, high cost of transactions during use of core banking services in the Nandyal town.

Suggestions

The status of the customer preference attribute before using core banking services was identified. The study suggested to the banks should provide awareness about the 
security/privacy issues for customers and also open ATM centers at public places as well as accessibility of services. It is further suggested that the banks should connect with the mobile network service providers for easy of usefulness and easy of perceive the basic services towards mobile and tele banking, among themselves for the transfer of funds, online cash payment etc., through ATMs without any service charges or any restrictions. The system of transactions through core banking services like ATM, online/internet banking, tele banking and mobile banking must be conveniently, speedy, accurate and reliable. Hence banks must ensure that the technology adopted by them is the latest and most efficient and hassle free for the customers.

\section{Limitations of the Study}

The present study also having some research limitations as follows:

$>$ The study was carried out at the micro level i.e., restricted only at Nandyal town.

$>$ The numbers of respondents were relatively small. Present study was conducted in the period from Oct 2013 to Jan 2014.

$>$ Non-probability purposive sampling method was applied in the selection of bank customers.

$>$ Findings of the study described on the basis of information provided by the respondents.

$>$ Mainly, the study concerted and investigate the customer preference attributes are to be consider while before usage of the Core banking services only.

\section{References}

IAMAI (2006) Online Banking 2006. Retrieved from http://www.iamai.in/Research.aspx?Fileid=r8_home.htm \&rid $=8$.
Khan MA (2010) An empirical study of Automated Teller Machine service quality and customer satisfaction in Pakistani banks. European journal of social sciences, 13(3): 333-344.

Katono IW (2011) Student evaluation of e-service quality criteria in Uganda: the case of automatic teller machines. International Journal of Emerging Markets, 6(3): 200-216.

Laukkanen T (2006) Consumer Value Drivers in Electronic Banking. Doctoral dissertation, Kuopio University Publications H. Business and Information Technology, pp.115.

Liu C and Arnett KP (2007) Exploring the factors associated with website success in the context of electronic commerce. Information \& Management, 13:431-43.

Mohan and Goyal G (2012) Customer perception towards Internet banking w.r.f to private and foreign banks in India. International Journal of Computing \& Business Research.

Nitsure R.R (2003) E-Banking: Challenges and Opportunities. Economic and Political Weekly, 38(51):5377-5381.

Safeena R, Abdullah and Date H (2010) Customer Perspectives on E-business Value: Case Study on Internet Banking. Journal of Internet Banking and Commerce, 15(1):1-13.

Srivastava KBL and Hazra SG (2009) Impact of service quality on customer loyalty, commitment and trust in the Indian banking sector, The IUP Journal of Marketing Management, 8(3/4):74-95.

Singhal D and Padhmanabhan V (2008) A Study on Customer Perception Towards Internet Banking: Identifying Major Contributing Factors. The Journal of Nepalese Business Studies, 5(1):102-111.

Williamson GD (2006) Enhanced Authentication in Online Banking. Journal of Economic Crime Management, 4(2):1-42. 